\title{
DIFFERENCES IN EFFECTIVENESS OF OCIMUM-SANCTUM 4\% GEL AND 25\% METRONIDAZOLE GEL POST SCALING ROOT-PLANING IN CHRONIC PERIODONTITIS
}

\author{
Vincensia Maria Karina*, Sri Pramestri Lastianny*, Rina Meiliyanawaty** \\ * Departamen Periodonsia, Fakultas Kedokteran Gigi, Universitas Gadjah Mada \\ ** Program Studi Periodonsia, Fakultas Kedokteran Gigi, Universitas Gadjah Mada \\ Correspondence : vincensia.maria.k@mail.ugm.ac.id
}

\begin{tabular}{|c|}
\hline Keywords: \\
$4 \%$ ocimum-sanctum, \\
scaling root planing, \\
chronic periodontitis, TNF- \\
$\alpha, \quad I L-1 \beta$ \\
\hline
\end{tabular}

\begin{abstract}
Background: Chronic periodontitis is a disease that causes inflammation of the tooth supporting tissue, loss of periodontal attachment, and loss of alveolar bone. Root planning scaling treatment is carried out to remove irritants and microorganisms. The use of additional materials is required when the pocket depth is more than $5 \mathrm{~mm}$. One of the herbal ingredients that has the potential as an adjunct to periodontal therapy is the $4 \%$ ocinumsanctum.

Method: The sample consisted of 20 periodontal pockets with a depth of 4-6 $\mathrm{mm}$ which were given scaling root planning which were divided into two groups, namely 10 pockets given 4\% maximum sanctum gel and 10 pockets given Metronidazole gel $25 \%$. evaluations of the papillary bleeding index, TNF- $\alpha$, and IL- $\beta$ were performed at baseline, and on day 21. TNF- $\alpha$ and IL- $\beta$ levels were taken through the gingival sulcus fluid and then tested using ELISA.

Result: Papillary bleeding index, TNF- $\alpha$, and IL- $\beta$ levels showed a significant reduction in both groups but there was no significant difference between the $4 \%$ ocimum sanctum group and Metronidazole gel.

Conclusion: ocimum sanctum application $4 \%$ post scaling root planning was able to lower papillary bleeding index score, TNF- $\alpha$ levels, and IL- $\beta$.
\end{abstract}

\section{PENDAHULUAN}

Tujuan terapi periodontitis menurut American Academy of Periodontology adalah untuk menyingkirkan mikroba penyebab dan faktor risiko periodontitis, sehingga dapat menghambat perkembangan penyakit, menjaga pertumbuhan gigi dalam keadaan sehat, nyaman, dan berfungsi dengan baik, memiliki estetika yang baik dan untuk mencegah rekurensi periodontitis (1). Penanganan awal pada kasus periodontitis adalah dengan scaling root planing (SRP) untuk mengurangi jumlah mikroorganisme sehingga dapat menurunkan kedalaman poket dan mengembalikan perlekatan jaringan. Antibiotik lokal telah digunakan sebagai terapi tambahan pasca SRP untuk mengobati periodontitis. Salah satu antibiotik yang sering digunakan adalah Metronidazole gel 25\% yang terbukti efektif memberikan efek klinis yang lebih baik ketika diapliksikan pasca SRP daripada SRP tanpa medikamen tambahan(2).

Ocimum sanctum merupakan tanaman herbal yang sering digunakan pada pengobatan karena mengandung berbagai senyawa antara lain yaitu flavonoid, saponin dan tanin yang banyak terdapat di dalam daun dan memiliki daya antimikroba (3). Irigasi subgingiva dengan ocimum. Sanctum 4\% terbukti efektif dalam mengurangi akumulasi plak, peradangan gingiva dan perdarahan pada paramater klinis gingival index, plaque index, pocket dept dan clinical attachment level dan tidak memiliki efek samping dibandingkan dengan klorheksidin(4). Penelitian ini bertujuan untuk mengkaji perbedaan efektivitas antara aplikasi gel $O$. sanctum $4 \%$ dan Metronidazole gel $25 \%$ pasca scaling root planing. 


\section{METODE PENELITIAN}

Penelitian ini merupakan penelitian semu dengan desain pretest posttest. Penelitian ini telah lolos kelaikan etik dengan nomor 00165/KKEP/FKG-UGM/EC/2019. Subjek pada penelitan ini berusia 30-45 tahun, memiliki poket periodontal 4-6 mm pada dua kuadran dan dipilih titik poket terdalam, tidak pernah menjalani perawatan periodontal sejak 6 bulan terakhir, bersedia menandatangani informed consent dan menyetujui untuk menjadi subjek penelitian. Sampel pada penelitian ini adalah 20 poket periodontal dengan kedalaman $4-6 \mathrm{~mm}$. Variabel yang diamati adalah kadar TNF- $\alpha$ dan IL-1 $\beta$ yang diukur pada baseline dan hari ke-21. Papillary bleeding index (PBI) diukur menggunakan probe UNC-15, penilaian menggunakan klasifikasi Saxer dan Muhlemann yaitu Skor 0 : tidak ada perdarahan; skor 1 : perdarahan berupa titik; Skor 2 : beberapa titik perdarahan atau satu garis perdarahan; Skor 3 : darah mengisi bagian interdental sesaat setelah probing; Skor 4 : perdarahan banyak setelah probing dan darah mengalir ke dalam sulkus marginal(5). TNF- $\alpha$ dan IL-1 $\beta$ diambil dari cairan sulkus gingiva menggunakan paper point no.30 yang kemudian dimasukkan ke dalam microcentrifuge tube yang sudah berisi PBS steril.

pasien diberikan terapi scaling root planing pada kunjungan pertama kemudian diberikan aplikasi O. sanctum gel $4 \%$ pada kelompok perlakuan dam Metronidazole gel 25\% pada kelompok kontrol. Kontrol dilakukan pada hari ke21 pasca scaling root planing, data yang diambil adalah pengukuran $\mathrm{PBI}$ dan pengambilan cairan sulkus gingiva.

Penghitungan kadar TNF- $\alpha$ dan IL-1 $\beta$ dilakukan dengan ELISA kit kemudian analisa data dilakukan dengan IBM SPSS 25 for windows dengan uji paired T-test.

\section{HASIL PENELITIAN}

Sebelum dilakukan uji statistik, semua data yang diperoleh pada baseline dan hari -21 dilakukan uji homogenitas menggunakan test of homogenity of variance (uji Levene) dan Saphirowilk untuk menentukan apakah data memiliki varietas yang sama. hasil dari uji tersebut menunjukkan $p>0,05$ sehingga diperoleh kesimpulan bahwa data homogen dan memiliki sebaran normal.

Tabel 1. Papillary Bleeding Index menurut waktu pengamatan dan kelompok perlakuan

\begin{tabular}{lccc}
\hline Hari & Ocimum santum Gel & Metronidazole Gel & Signifikansi \\
& $4 \%$ & $25 \%$ & \\
\hline Baseline & $3(2-3)$ & $3(2-4)$ & 0.411 \\
\hline Hari - 21 & $0(0-0)$ & $0(0-1)$ & 0.317 \\
\hline
\end{tabular}

Data baseline menunjukkan bahwa pada kedua kelompok memiliki rata-rata skor PBI 3 dan data pengamatan hari-21 menunjukkan bahwa pada kedua kelompok memiliki rata-rata skor PBI 0. Hasil uji Mann Whitney pada baseline dan hari-21 menunjukkan tidak terdapat perbedaan yang signifikan antara kedua kelompok perlakuan. ilustrasi skor PBI antara kelompok Ocimum santum gel $4 \%$ dan metronidazole $25 \%$ gel baik baseline dan hari-21 ditampilkan pada gambar 1 . 


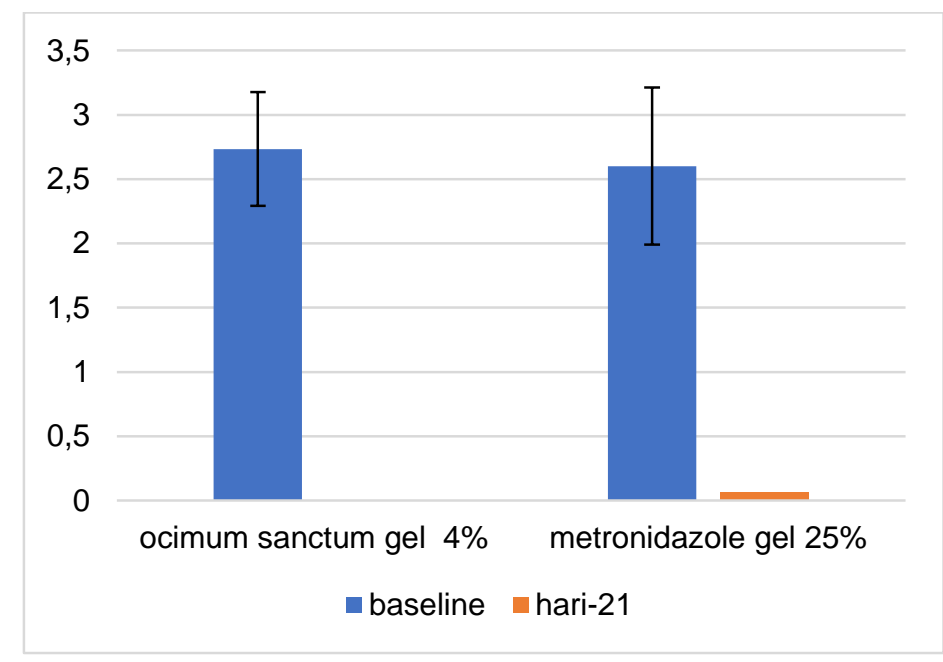

Gambar 1. Grafik rerata Papillary Bleeding Index menurut waktu pengamatan dan perlakuan

Perbedaan kadar antara TNF $\alpha$ dan IL-1 $\beta$ pada kelompok Ocimum sanctum $4 \%$ gel dan metronidazole $25 \%$ gel baik baseline dan hari-21 ditampilkan pada tabel 2 dan gambar 2 .

Tabel 1. Rerata Kadar dan standar deviasi TNFa dan IL-1 $\beta$ menurut waktu pengamatan dan kelompok perlakuan

\begin{tabular}{lcccc}
\hline Hari & \multicolumn{2}{c}{ TNF- $\alpha$} & \multicolumn{2}{c}{$\mathrm{IL}-1 \beta$} \\
\hline & Ocimum santum & Metronidazole & Ocimum & Metronidazole \\
& gel & gel & santum gel & gel \\
& $4 \%$ & $25 \%$ & $4 \%$ & $25 \%$ \\
\hline Baseline & $8,76 \pm 1,8$ & $9,54 \pm 1,5$ & $6,906 \pm 2,7$ & $9,54 \pm 1,56$ \\
\hline Hari-21 & $1,516 \pm 1,05$ & $1,104 \pm 0,5$ & $1,1 \pm 0,67$ & $0,89 \pm 0,56$ \\
\hline
\end{tabular}

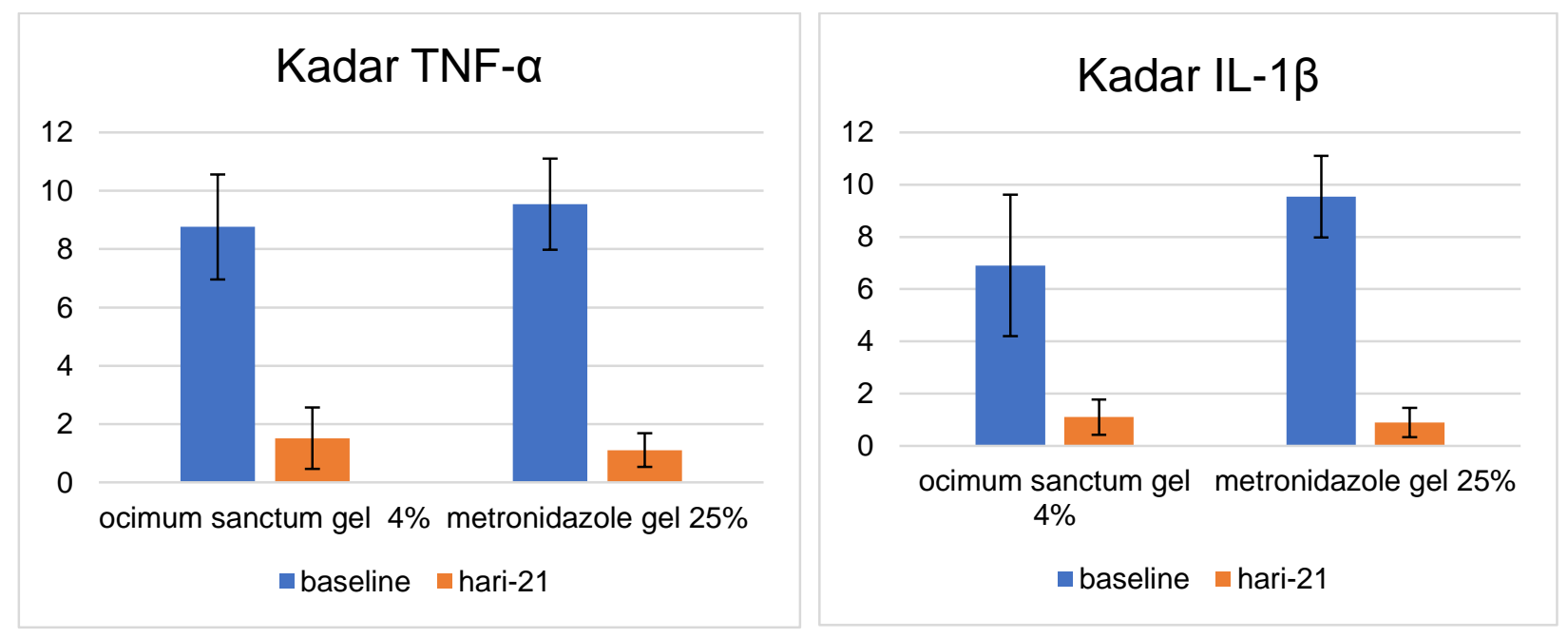

Gambar 2. Grafik rerata Kadar TNF- $\alpha$ dan IL-1 $\beta$ menurut waktu pengamatan dan kelompok perlakuan

Uji Paired T-test dilakukan untuk mengetahui Perbedaan kadar antara TNF- $\alpha$ dan IL-1 $\beta$ pada kelompok Ocimum santum gel $4 \%$ dan
Metronidazole gel $25 \%$ antara waktu pengamatan yang ditampilkan pada tabel 3. 
Tabel 3. Uji Paired T-test menurut waktu pengamatan dan kelompok perlakuan

\begin{tabular}{|c|c|}
\hline Perbandingan Kadar & Signifikansi \\
\hline $\begin{array}{l}\text { TNF- } \alpha \text { Ocimum sanctum gel } 4 \% \text { baseline dan TNF } \alpha \\
\text { Ocimum sanctum gel } 4 \% \text { hari- } 21\end{array}$ & $0.000^{*}$ \\
\hline $\begin{array}{c}\text { TNF- } \alpha \text { Metronidazole gel } 25 \% \text { baseline dan TNF } \alpha \\
\text { Metronidazole gel } 25 \% \text { hari- } 21\end{array}$ & $0.000^{*}$ \\
\hline $\begin{array}{l}\text { IL-1 } 1 \beta \text { Ocimum sanctum gel } 4 \% \text { baseline dan TNF } \alpha \\
\text { Ocimum sanctum gel } 4 \% \text { hari- } 21\end{array}$ & $0.000^{*}$ \\
\hline 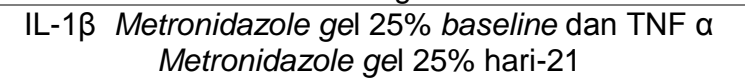 & $0.000^{*}$ \\
\hline
\end{tabular}

Uji Independent T-test dilakukan untuk mengetahui Perbedaan kadar antara kelompok Ocimum santum gel $4 \%$ dan Metronidazole gel 25\% pada kadar
TNF- $\alpha$ dan IL-1 $\beta$ pada dalam waktu pengamatan yans sama, yang ditampilkan pada tabel 4 .

Tabel 4. Uji Independent T-test menurut waktu pengamatan dan kelompok perlakuan

\begin{tabular}{|c|c|}
\hline Perbandingan Kadar & Signifikansi \\
\hline $\begin{array}{l}\text { TNF- } \alpha \text { Ocimum sanctum gel } 4 \% \text { baseline dan TNF a } \\
\text { Metronidazole gel } 25 \% \text { baseline }\end{array}$ & 0.340 \\
\hline $\begin{array}{c}\text { TNF-a Ocimum sanctum gel } 4 \% \text { hari-21 dan TNF a } \\
\text { Metronidazole gel } 25 \% \text { hari-21 }\end{array}$ & 0.980 \\
\hline $\begin{array}{l}\text { IL-1 } 1 \beta \text { Ocimum sanctum gel } 4 \% \text { baseline dan TNF } \alpha \\
\text { Metronidazole gel } 25 \% \text { baseline }\end{array}$ & 0.021 \\
\hline $\begin{array}{c}\text { IL-1 } \beta \text { Ocimum sanctum gel } 4 \% \text { hari-21 dan TNF } \alpha \\
\text { Metronidazole gel } 25 \% \text { hari- } 21\end{array}$ & 0.484 \\
\hline
\end{tabular}

\section{DISKUSI}

Terdapat penurunan skor papilla bleeding index (PBI) pada kelompok Ocimum sanctum gel $4 \%$ dan Metronidazole gel 25\%, namun jika dibandingkan antara kedua kelompok perlakuan tersebut tidak terdapat perbedaan yang signifikan. Senyawa saponin pada Ocimum sanctum berfungsi sebagai immunomodulator yang dapat meningkatkan proliferasi monosit serta menstimulasi monosit untuk berdiferensiasi menjadi makrofag sehingga meningkatkan jumlah makrofag. Hal ini sekaligus meningkatkan sekresi growth factor seperti FGF, PDGF, TGF- $\beta$ dan EGF, yang meningkatkan fibroblas ke daerah luka sehingga sintesis kolagen juga meningkat dan terbentuk connective tissue matrix. Saponin juga berfungsi sebagai anti bakteri yang dapat menyebabkan kebocoran protein dan enzim dari dalam sel melalui penurunan tegangan permukaan dinding sel bakteri dan merusak permebialitas membran(6)

Ocimum sanctum memiliki beberapa efek terapi, antara lain antimikroba dan imunomodulator. Hal ini dikarenakan kandungan kimia aktif yang terdapat pada 0 . Sanctum antara lain yaitu flavonoid, tanin, phlobatannin, saponin, steroid, karbohidrat, terpenoid, antrakinon, dan minyak atsiri(7). Ocimum sanctum telah diuji dapat melawan berbagai mikroorganisme dan isolat klinis Staphylococcus aureus yang resisten methicillin beta-lactamase. Beberapa penelitian menjelaskan mekanisme bakterisidal dari eugenol, alpha terpinol dan gama terpine yang merupakan komponen utama dalam minyak esensial dalam melawan tes antimikroba. Ocimum sanctum mengandung flavonoid, tanin, phlobatannin, saponin, steroid, karbohidrat, terpenoid, antrakinon, glikosida 
jantung, alkaloid, dan minyak atsiridan kandungan kimia lainnya(8). Ocimum sanctum $4 \%$ terbukti efektif karena kemampuannya dalam mengurangi plak akumulasi, peradangan gingiva dan perdarahan dan tidak memiliki efek samping dibandingkan dengan klorheksidin(9).

Kadar TNF- $\alpha$ dan IL-1 $\beta$ pada masing-masing kelompok perlakuan menunjukkan terjadi penurunan yang signifikan dari baseline ke hari-21. TNF- $\alpha$ dan IL-1 $\beta$ merupakan sitokin preinflamatori yang terlibat dalam remodeling tulang, resorpsi tulang, dan deposisi tulang baru. Kedua sitokin tersebut merupakan sitokin utama dan media inflamasi yang diproduksi dan diaktivasi oleh makrofag. TNF- $\alpha$ dan IL-1 $\beta$ banyak terlibat dalam kondisi inflamasi(10). Penurunan yang terjadi pada penelitian ini menunjukkan adanya perbaikan kondisi jaringan periodontal. Hal ini sejalan dengan pernyataan Tawfig (2016) yang menyatakan bahwa peningkatan kadar IL-1 $\beta$ dalam gingiva dapat menjadi indikator terjadinya periodontitis. Penurunan kadar IL-1 $\beta$ setelah terapi periodontal menunjukkan keberhasilan dari terapi tersebut(11).

Kadar TNF- $\alpha$ dan IL-1 $\beta$ antara kelompok Ocimum sanctum gel $4 \%$ dengan TNF $\alpha$ Metronidazole gel 25\% saat baseline dan hari-21 menunjukan tidak terdapat perbedaan yang signifikan. Hal ini menunjukkan bahwa ocimum sanctum gel $4 \%$ memiliki kemampuan yang sama dengan Metronidazole gel 25\% dalam menurunkan inflamasi. Metronidazole gel mampu menekan bakteri Porphyromonas Gingivalis yang kemudian mampu menekan pula produksi TNF- $\alpha$ dan IL$1 \beta(12)$. Ocimum sanctum mampu berperan sebagai anti gingivitis dan anti inflamasi. Kandungan Civsilineol, Civsimavatine, Isothymonin, Apigenin, Rosavinic acid dan Eugenol diketahui memiliki aktivitas antiinflamasi atau mengambat cyclooxygenase(4).

\section{KESIMPULAN}

Ocimum sanctum gel $4 \%$ memiliki kemampuan yang sama efektif dengan dengan Metronidazole gel 25\% dalam menurunkan skor papillary bleeding index, serta kadar TNF- $\alpha$ dan IL$1 \beta$ setelah scaling dan root planing pada penderita periodontitis kronis.

\section{UCAPAN TERIMAKASIH}

Terima kasih kami ucapkan kepada hibah dana masyarakat Fakultas Kedokteran Gigi Universitas Gadjah Mada yang telah mendanai penelitian ini.

\section{DAFTAR PUSTAKA}

1. Carranza et al. https://t.me/LibraryEDent. 2018. 127-150 p.

2. Trijani S. Efek Klinis Aplikasi Subgingival Racikan Gel Metronidasol 25\% dan Larutan Povidon-lodin $10 \%$ sebagai Terapi Penunjang Skeling-Penghalusan Akar pada Periodontitis Kronis [Tesis]. Fak Kedokt Gigi Univ Indones. 2003;

3. Cohen MM. Tulsi - Ocimum sanctum: A herb for all reasons. J Ayurveda Integr Med. 2014;5(4):251-9.

4. Gupta D, Bhaskar DJ, Gupta RK, Karim B, Jain A, Singh $R$, et al. A randomized controlled clinical trial of Ocimum sanctum and chlorhexidine mouthwash on dental plaque and gingival inflammation. $\mathrm{J}$ Ayurveda Integr Med. 2014;5(2):109-16.

5. Bessa Rebelo MA, de Queiroz AC. Gingival Indices: State of Art. Gingival Dis - Their Aetiol Prev Treat. 2011;(September 2011).

6. Madduluri S, Babu Rao K, Sitaram B. In vitro evaluation of antibacterial activity of five indigenous plants extract against five bacterial pathogens of human. Int J Pharm Pharm Sci. 2013;5(SUPPL.4):679-84.

7. Saputri FC, Zahara R. Uji Aktivitas AntiInflamasi Minyak Atsiri Daun Kemangi (Ocimum americanum L.) pada Tikus Putih Jantan yang Diinduksi Karagenan. Pharm Sci Res. 2016;3(3):107-19.

8. Issazadeh K, Reza M, Khoshkholgh M, Bidarigh S, Giahi M, Muradov PZ. International Journal of Molecular and Clinical Microbiology Analysis of the Phytochemical Contents and Anti-microbial Activity of Ocimum basilicum L. Phytochem 
Anal. 2012;1:141-7.

9. Gaur J, Chandra J, Chaudhry S, Vaish S, Dodwad V. Assessment of $4 \%$ ocimum sanctum and $0.2 \%$ chlorhexidine irrigation as an adjunct to scaling \& root planing in management of chronic periodontitis-a randomized controlled trial. J Dent Spec. 2015;3(2):217.

10. Afshar MK, Safarian F, Torabi M, Farsinejad A, Mohammadzadeh I. Comparison of TNF- $\alpha$ and IL-1 $\beta$ concentrations in gingival crevicular fluid during early alignment stage of orthodontic treatment in adults and adolescents.
Pesqui Bras Odontopediatria Clin Integr. 2020;20:1-8.

11. Tawfig N. Proinflammatory Cytokines and Periodontal Disease. J Dent Probl Solut. 2016;3:012-7.

12. Rizzo A, Paolillo R, Guida L, Annunziata M, Bevilacqua N, Tufano MA. Effect of metronidazole and modulation of cytokine production on human periodontal ligament cells. Int Immunopharmacol [Internet]. 2010;10(7):744-50. Available from: http://dx.doi.org/10.1016/j.intimp.2010.04.0 04 